DOI https://doi.org/10.15589/znp2021.1(484).15

УДК 330.46

\title{
CHAOS THEORY IN THE BUSINESS SPACE
}

\section{ТЕОРІЯ ХАОСУ НА ПІДПРИЕМНИЦЬКОМУ ПРОСТОРІ}

\author{
Kseniia Yu. Vzhytynska \\ kvzhytynsra@gmail.com \\ ORCID: 0000-0002-3618-664X
}

\author{
К. Ю. Вжитинська, \\ канд. екон. наук, доцент
}

National University of Food Technologies, Kyiv

Начіональний університет харчових технологій, м. Київ

\begin{abstract}
Each enterprise, as well as an individual household, a person in one way or another has certain goals and plans for the future. They can be of completely different nature: economic, social, political, and so on. However, they are clearly united by a range of factors influencing the relevant processes that directly or indirectly affect the expected result. Sufficient attention has been paid to the study of the factors of influencing factors. They are clearly defined and divided according to classification criteria.

However, what do we know about the degree of influence of each and their domesticity?

The randomness of the factors influencing the efficiency of the enterprise can be compared with their chaos, the detection of which will allow for more detailed analysis, forecasting and planning in the enterprise. This will allow a more detailed study of chaos theory.

According to the literature, chaos theory suggests that complex systems are extremely dependent on the initial conditions of existence, and even minor changes in the environment can lead and will eventually lead to unpredictable consequences.

The purpose of the study is to determine whether there is a chaos of factors influencing the efficiency of the enterprise as a whole.

Results: the definition of the importance of chaos in the process of enterprise management is formed, the connection with chaos and stages of activity of enterprises is considered, the essence of self-regulated system, self-regulated criticality and chaos in business space is determined.

Scientific novelty: the scheme of sequence of the organization of chaos is defined, connection of stations of chaos with cycles of activity of the enterprises is offered.

The practical significance lies in the creation of a theoretical basis for further development of methods and models of chaos management in the enterprise, the further use of which will increase the efficiency of enterprises.

Key words: influencing factors; chaos; chaos theory; self-sufficiency system; self-organized criticality; order; cyclicity; fractal.
\end{abstract}

Анотація. Кожне підприємство, як і окреме домогосподарство чи особа, так або інакше має певні цілі та плани на майбутнє. Вони можуть бути абсолютно різного характеру: економічного, соціально-політичного тощо. Проте однозначно їх поєднує спектр факторів впливу на відповідні процеси, що прямо чи опосередковано впливають на очікуваний результат.

Вивченню проблематики факторів впливу приділено досить уваги. Вони чітко визначені та поділені згідно 3 класифікаційними ознаками. Однак, що нам відомо про ступінь впливу кожного і про їхню рандомність?

Рандомність факторів упливу на ефективність діяльності підприємства можна порівняти з їхньою хаотичністю, виявлення якої дасть змогу здійснювати більш детальний аналіз, прогнозування та планування на підприємстві. Це дозволить зробити більш детальне вивчення теорії хаосу.

Згідно з опрацьованими літературними джерелами теорія хаосу передбачає, що складні системи надзвичайно залежні від початкових умов існування, і навіть незначні зміни в навколишньому середовищі можуть призвести та згодом призведуть до непередбачуваних наслідків.

Мета - визначити, чи має місце хаотичність факторів впливу на ефективність діяльності підприємства в цілому. Результати: сформовано визначення вагомості хаотичності в процесі управління підприємствами, розглянуто зв'язок з хаосом та стадіями діяльності підприємств, визначено сутність саморегульованої системи, саморегульованої критичності та хаосу на підприємницькому просторі.

Наукова новизна: визначено схему послідовності організації хаосу, запропоновано зв'язок стадій хаосу із циклами діяльності підприємств. 
Практична значимість полягає у створенні теоретичного підгрунтя для розроблення методів і моделей управління хаосом на підприємстві, подальше використання яких дозволить підвищити ефективність діяльності підприємств.

Ключові слова: фактори впливу; хаос; теорія хаосу; система самодостатності; самоорганізована критичність; порядок; циклічність; фрактал.

\section{ПОСТАНОВКА ЗАДАЧІ}

Зрозуміло, якщо певне домогосподарство прагне мати більші доходи, його учасники повинні працювати більше ефективно, щоб заробляти більше. Для людини, яка має роботу та працює як найманий працівник, основний дохід буде становити заробітна плата. У свою чергу на величину заробітної плати може впливати низка чинників: розмір мінімальної заробітної плати, оплата фіксованої ставки, рівень оподаткування, якість освіти та наявність досвіду тощо. Однак якщо людина влаштується, припустимо, прибиральником, ці всі дуже суттєві фактори значно знижують свій вплив і виступають уже інші, більш важливі для даної ситуації, наприклад: кількість прибраних об’єктів, відпрацьовані години, швидкість виконання поставлених завдань та ін.

Тобто можна чітко стверджувати, що для кожного конкретного об'єкта та за відповідних обставин фактори впливу змінюються. Причому закономірність у даному питанні є досить поверховою. Фактори впливу можуть з'являтися хаотично і так само зникати. Та чи є можливість управляти хаотичною системою та використовувати подібні навички на рівні підприємства, домогосподарства тощо?

\section{АНАЛІЗ ОСТАННІХ ДОСЛІДЖЕНЬ ТА ПУБЛІКАЦІЙ}

Останнім часом дослідженню поставленої проблематики приділено мало уваги. Але окремого інтересу заслуговують дослідження К. Мамедової [4], О. Черняк, П. Захарченко [2; 3], особливо більш стара праця Т. Мена [1], в якій визначаються загальні теоретичні положення визначення хаосу та теорії хаосу.

\section{ВІДОКРЕМЛЕННЯ НЕ ВИРІШЕНИХ РАНІШЕ ЧАСТИН ЗАГАЛЬНОЇ ПРОБЛЕМИ}

На наш погляд, кількість та якість факторів (систему формування їх кількості та якості), що мають вплив на певне явище чи об' єкт аналізу, можна порівняти з хаотичною системою. Це пояснюється унікальністю кожного випадку або об'єкту, а також процесу його адаптації під постійно змінювані умови.

\section{МЕТА ДОСЛІДЖЕННЯ}

Мета - визначити, чи має місце хаотичність факторів впливу на ефективність діяльності підприємства в цілому.

\section{МЕТОДИ, ОБ'ЄКТ ТА ПРЕДМЕТ ДОСЛІДЖЕННЯ}

Методи дослідження: метод порівняння, екстраполяції, аналізу та метод синтезу.
Об'єкт дослідження - доцільність і можливість удосконалення аналізу ефективності діяльності підприємств з урахуванням циклічності хаосу.

Предметом дослідження є процес впливу циклічності хаосу на ефективність діяльності підприємств.

\section{ОСНОВНИЙ МАТЕРІАЛ}

Варто зауважити, що питання хаотичності в економіці є досить актуальним і своєчасним. Подібними дослідженнями займалися та досі займаються багато вчених.

Отже, що нам відомо про хаос як такий та про його похідну - теорію хаосу?

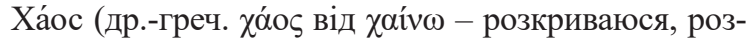
верзаюся) - категорія, яка використовується протилежно до терміна «порядок». У більш повсякденному виразі хаос розуміють як безлад, плутанину, змішання.

У математиці хаосом називається аперіодично детермінована поведінка динамічної системи, вкрай чутлива до початкових умов. Нескінченно мале обурення граничних умов для хаотичної динамічної системи призводить до кінцевої зміни траєкторії у фазовому просторі [2, с. 32-34].

Звичайно, дана дефініція мало розкриває вибрану проблематику на рівні підприємства, саме тому, на наш погляд, варто звернутися до більш свіжіших досліджень. Причому цікавить нас саме теорія хаосу, спроектована на економічний простір.

Початківцями даної теорії можна вважати французького фізика А. Пуанкаре (теорема про повернення), радянських математиків А.Н. Колмогорова i В.І. Арнольда й німецького математика Ю.К. Мозера, які вперше запропонували теорію хаосу (КАМ). Запропонована теорія включає в своє теоретичне поле поняття атракторів, тобто тих, хто привертає увагу, залучає.

Теорія хаосу стверджує, що складні системи надзвичайно залежні від початкових умов існування, і навіть незначні зміни в навколишньому середовищі можуть призвести та згодом призведуть до непередбачуваних наслідків.

Математичні та економічні системи з хаотичною поведінкою є детермінованими, тобто підкорюються закону, і в певному сенсі є впорядкованими. Тобто дане дослідження дозволило розширити поняття хаосу та надати йому додаткових функцій [3, с. 89-91].

Проте подібні визначення задавали більше питань, ніж давали відповідей, що і призвело до подальших досліджень у даному напрямі.

У 1972 році синоптик Едвард Лоуренц ум. Вашингтон явив світу свою статтю «Передбачення: 
помах крил метелика в Бразилії може спричинити торнадо в Техасі», в якій вперше підняв питання «Ефекту метелика».

Іншими словами, кількість факторів впливу на кінцевий об'єкт аналізу незліченний. Якщо говорити більш конкретно, то результатами даного дослідження стала суттєва різниця в округленні Лоуренцом даних для аналізу до шостого знаку після коми, що спричинило кардинально протилежний результат у розрахунках. Тобто коли для аналізу використовувалося повне число, результат був одним, а після округлення цифр для подальших розрахунків на міліонну після коми це давало протилежні результати.

Відомі випадки, коли округлення в результатах економічного аналізу призводило також до різних висновків. Так, за результатами факторного аналізу прибутку, наприклад, у разі округлення, вагомість впливу одного фактору буде суттєво знижена, а іншого - на цьому фоні збільшиться.

Отже, можна сміливо стверджувати, що дана закономірність притаманна і майже всім видам економічного аналізу. Тобто визначати фактори впливу допустимо лише поверхово і суб'єктивно. Подолати цю суб'єктивність можливо за допомогою комп'ютерних технологій, хоча прогнози таких масштабів з максимальною точністю на даному етапі розвитку світу не під силу навіть машинам. Наприклад, прогнози погоди постійно мають неточності, іноді навіть суттєві, попри залучені комп’ютерні технології останнього покоління.

Із безлічі інших робіт, присвячених теорії хаосу, ми би хотіли виділити дослідження Пера Бака, Чао Тана та Курта Вісенфелда, які в 1987 році вперше описали систему самодостатності (далі - СС). Згідно 3 їхньою статтею СС є одним із природних механізмів і основною ланкою в процесі пояснення спектру природних явищ. Такими явищами можуть бути коливання в економічних системах, у прибутках або збитках, рівнях конкурентоспроможності тощо.

Якщо враховувати нестабільний та безмасштабний розподіл можливих випадків виникнення, можна запропонувати СС як приклад виникнення економічних криз, як на рівні підприємства, так і на інших рівнях. У такому разі подібне моделювання може включати в себе декілька варіантів:

- розроблення нових моделей;

- пристосування вже розроблених та ефективно функціонуючих моделей до даної реальної системи.

Якщо проектувати СС в економічний простір, то можна стверджувати, що система самодостатності економічного об'єкта - це система самодостатності та певної ефективності економічних показників цього об'єкта. Тобто це економічний стан, який влаштовує/ частково влаштовує власника чи керуючу особу.

Також уваги, на наш погляд, заслуговує робота визначного політолога Стіва Манна «Теорія керова- ного хаосу». Він видав цю статтю у 1992 році, а також підготував іншу свою знамениту працю, що отримала великий резонанс у військово-політичному співтоваристві: «Теорія хаосу і стратегічна думка». У цій публікації стверджується, що теорія «керованого хаосу» - це сучасний феномен, геополітична доктрина, яка йде своїм корінням у найдавніші науки, такі як філософія, математика, фізика, економіка.

Спроби та способи наукового осмислення таких понять, як «порядок» i «хаос», сформували теорії спрямованого безладу, великі класифікації і типології хаосу. У найдавнішої історико-філософської традиції хаос розумівся як такий, що все собою обіймає і породжує початок.

У цій науковій роботі С. Манн викладає таке: «Международная среда является превосходным примером хаотической системы <... «самоорганизованная критичность» <..> соответствует ей в качестве средства анализа <..> Мир обречен быть хаотичным, потому что многообразные акторы человеческой политики в динамической системе <...> имеют разные цели и ценности. Каждый актор в политически критических системах производит энергию конфликта, <..> которая провоцирует смену статус-кво, участвуя, таким образом, в создании критического состояния <... $>$, и любой курс приводит состояние дел к неизбежному катаклизменному переустройству» [1, с. 54-68].

Отже, можна констатувати, що теорія «керованого хаосу» - це складна доктрина, яка піддається аналізу лише частково, оскільки людський розум не може використати всі фактори впливу на дослідний феномен.

Але на окрему увагу заслуговує термін «самоорганізована критичність» (СК). Згідно з вищевикладеним це певний стан дослідного об'єкта, який може наступати після або до стану самоорганізованої системи і який існує в просторі теорії хаосу. На наше переконання, якщо цей процес зобразити схематично, то він буде мати такий вигляд:

Отже, 3 вищенаведеного видно, що хаос можна організувати, проте подібна організація є досить поверховою. Очевидно, що хаос прямо пов'язаний iз самоорганізованою критичністю. Це $є$ логічним, оскільки в процесі управління будь-яким об'єктом чи процесом відбувається підпорядкування однієї системи іншій, інакше кажучи, в даному випадку сублімація своїх цілей фізичними чи юридичними особами на площину хаосу з метою впорядкування іiї до певної організованої критичності.

Тобто, наприклад, якщо це підприємство, то першим кроком для його становлення у всій хаотичній системі буде створення цього підприємства, визначення його цілей та специфіки діяльності, форми правління, умов функціонування, стратегії спрямування до беззбитковості або одразу до прибутковості, визначення стратегії та тактики підприємства тощо. 


\section{ЕКОНОМІКА ТА МЕНЕДЖМЕНТ №1_2021}

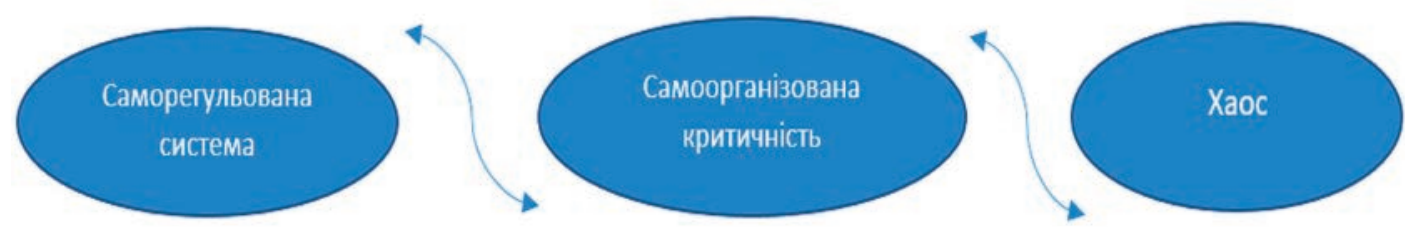

Рис. 1. Схема послідовності організації хаосу
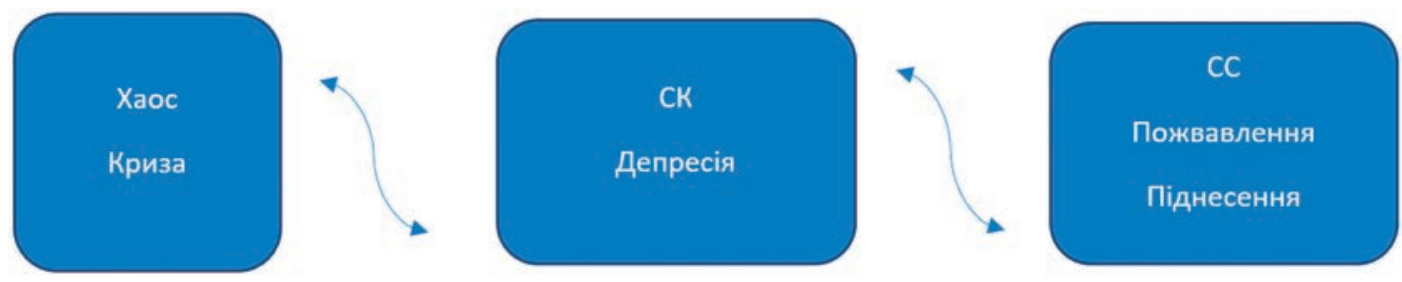

Рис. 2. Циклічність та хаотичність

$€$ абсолютно логічним той крок, який буде першим у процесі поступового та часткового опанування хаосу, оскільки ми чітко переконані, що хаос можна подолати тільки частково. Логічним є твердження, що система з будь-якої точки дисбалансу поступово прийде до рівноваги. Проте як бути в такому разі з такими антагоністами, як хаос та порядок?

За саморегульованої системи всі показники діяльності підприємства $є$ ефективними, діяльність - прибутковою. Підприємство поступово займає свою нішу та задовольняє споживачів, конкурує. У такому разі відповіддю стає саморегульована система. Вона може стати результатом регульованої критичності, проте переважно в результаті ефективного управління. Похибки в процесі управління та використання мінімальної кількості факторів упливу рано чи пізно знову призводять до критичності, а згодом - i до хаосу. Звичайно, ефективний менеджмент має можливість продовжити життєдіяльність підприємства, організації. Але неминучість змін різного роду: політичних, соціальних, демографічних, економічних, екологічних тощо призведе до занепаду і хаосу.

Хаос теж підпорядковується циклічності. Тобто якщо хаос $\epsilon$ початком, то хаос можна вважати і кінцем. Імовірно, це кінець процесу управління з метою отримання певного результату. У такому випадку підприємство просто ліквідується або проходить стадію кризи. Стадія депресії більш відповідає стадії саморегульованої критичності, а пожвавлення та піднесення віднесемо до саморегульованої системи.

У такому разі доцільним буде припущення, що стадії піднесення та пожвавлення можливі й за хаотичних умов. Просто «помах крил метелика у Бразилії спричинив не тільки торнадо в Техасі», але ще й створив сприятливі умови для певного виробництва чи для певної групи підприємств. Ці висновки знову повертають дослідження до вищезазначеного висновку: хаос малоймовірно впорядкувати.

Порушуючи питання циклічності хаосу, треба зауважити, що певні спроби вже були зроблені. Дані цикли чи періоди були названі фракталами.

Згідно з визначенням фрактал (лат. Fractus - зламаний, розбитий, подрібнений) - безліч, що має властивість самоподібності. Фрактал прийнято вважати єдиним порядком у хаосі.

Так, Трикутник Серпинського, Папороть Канслі, Губка Менгера, Крива Пеано, Безліч Кантора - це все приклади фракталів, які були створені на основі ітерації (принципу повторювальності).

Отже, згідно з фракталами, які створюються 3 хаосу, можна стверджувати, що хаотичність не являє собою безладність, а $є$ впорядкованою системою. Система може у свою чергу бути стійкою та нестійкою.

Стійка система відповідно до математичних та економічних законів - це система, яка за малих змін початкових умов отримує малі зміни в результаті. Припустимо, підприємство має дохід на рівні 100 тис. гривень. Усі витрати будуть 60 тис. гривень. Тобто прибуток 40 тис. Якщо витрати зміняться на $10 \%$, то на $10 \%$ зміниться і прибуток. Це стійка система.

Чим складніша система, тим більше вона $є$ нестійкою, оскільки неможливо абсолютно точно спрогнозувати її поведінку. Саме нестійка система є об'єктом вивчення теорії хаосу, оскільки одна упущена деталь може привезти до колосальних наслідків. Також варто зауважити, що чим масштабніший прогноз, тим він буде менш точним.

Взагалі, процес управління підприємством і $є$ прикладом нестійкої системи, оскільки кількість факторів впливу на ефективну діяльність просто незліченна.

Процес опанування управління нестійкої системи варто розпочати з аналізу існуючих даних, а вже після цього можна переходити до прогнозування. 


\section{ВИСНОВКИ}

За результатами вищевикладеного ми пропонуємо звернути більшу увагу не на прогнозування, а на оцінку стартових даних підприємства або на аналіз його поточного стану. Тобто задати питання: що б могло запобігти або перешкодити поточним позитивним моментам? А також що стало результатом позитивних результатів сьогодення?

Покроковий аналіз уже отриманих результатів дасть більше розуміння процесів функціонування окремого об'єкта, дозволить винайти упущені можливості та альтернативи розвитку.

Отже, розуміння сутності хаосу відповідає на багато питань, проте постійно з'являються нові, відповіді на які економічна спільнота шукає і сьогодні. Проте поступова і навіть поверхова систематична розгадка цих «темних плям» у процесі управління та в економіці загалом дозволить отримати довгоочікувані результати та відповіді на питання, які сприятимуть поступовому перенесенню управління та прогнозування на принципово якісно новий рівень.

\section{REFERENCES}

[1] Mann, Steven R. (1992). Chaos Theory and Strategic Thought. US Army War College Quarterly, Vol. XXII. P. 54-68.

[2] O.I. Cherniak, P.V. Zaharchenko, T. C. Klebanova. (2014). Teoria haosu v economici: pidr. /- Berdiansk : Tkachuk O.V. P. $244 \mathrm{c}$

[3] Kolmogorov A.N. (2004). Elementy teorii funkciy I funkcionalnogo analisa. 7-e isdanye. Moskva: Fizvatlit. P. 560.

[4] Kamila Mamedova. (2019). Teoria haosy abo yk pobachity efekt metelyka. Resaved from: https://naukatehnika.com/ teoriya-xaosa-effekt-babochki.html

\section{СПИСОК ВИКОРИСТАНОЇ ЛІТЕРАТУРИ}

[1] Mann, Steven R. (1992). Chaos Theory and Strategic Thought. US Army War College Quarterly. Vol. XXII. P. 54-68.

[2] Черняк, О. І. Захарченко, П. В. Клебанова, Т. С. (2014). Теорія хаосу в економіці : підруч. Бердянськ : Видавець Ткачук О.В. С. 244 с.

[3] Колмогоров, А. Н. (2004). Элементы теории функций и функционального анализа. 7-е издание. Москва : Физматлит. C. 560 .

[4] Мамедова, К. (2019). Теорія хаосу або як побачити ефект метелика? URL: https://naukatehnika.com/teoriyaxaosa-effekt-babochki.html 